\title{
Violence against children: an analysis of mandatory reporting of violence, Brazil 2011
}

\author{
Susana Maria Moreira Rates ${ }^{1}$ \\ Elza Machado de Melo ${ }^{2}$ \\ Márcio Dênis Medeiros Mascarenhas ${ }^{3}$ \\ Deborah Carvalho Malta ${ }^{3}$
}

${ }^{1}$ Gerência de Regulação, Secretaria Municipal de Saúde de Belo Horizonte. Av. Afonso Pena $2.336 / 10^{\circ}$, Funcionários. 30130007Belo Horizonte MG Brasil.susana.rates@ hotmail.com

${ }^{2}$ Coordenação do Núcleo de Promoção de Saúde e Paz, Programa de PósGraduação em Saúde Pública, Departamento de Medicina Preventiva e Social, Faculdade de Medicina, Universidade Federal de Minas Gerais. ${ }^{3}$ Departamento de Vigilância de Doenças e Agravos Não Transmissíveis e Promoção da Saúde, Secretaria de Vigilância em Saúde, Ministério da Saúde.

\begin{abstract}
This article aims to describe and analyze reporting of violence against children from 0 to 9 years of age, issued by the public health services, in Brazil. Data from the Violence and Accident Surveillance System (Viva-SINAN) were used. The frequency of selected variables was calculated by age group (0-1; 2-5 and 6-9 years of age) as well as their Prevalence Ratios (PR). 17.900 cases were reported: $33 \%$ in the $0-1$ year group; $35,8 \%$ in the 2-5 year group; and 31,2\% in the 6-9 year group. Physical violence predominated among boys (PR: 1.22; CI 95\%: 1,16-1,28); 6-9 years old (PR: 1,19; CI 95\%: 1,12-1.27). Sexual violence predominated among girls, mulatto/ afro-descendant (PR: 1.12; CI $95 \%$ : 1.06 to 1.19 ); 6-9 years (PR: 4.63; CI 95\%: 4.22- 5.08) with more chances of occurring at home (PR: 1.38, CI: 95\%: 1.29-1.48); psychological violence prevailed among girls, mulatto/afro-descendant (PR: 1.10; CI 95 \%: 1.03-1.18 ), 6-9 years old (PR: 2.95; CI 95\%: 2.69- 3.23), at home (PR: 1.40; CI 95\%: 1.29-1.53); negligence predominated among boys (PR: 1.33 ; 95\% CI: 1.27-1.39); 0-1 years and their parents were the most prevalent perpetrators. The results indicate the need to strengthen intersectoral actions aiming at extending the social protection and care network.

Key words Domestic violence, Child abuse, Epidemiology, Reporting of violence
\end{abstract}




\section{Introduction}

Violence against children is a universal phenomenon; the World Health Organization (WHO) recognizes it as a public health concern worldwide, affecting millions of children, families and communities every year ${ }^{1-6}$. The inclusion of this topic in the health agenda, which started in the $60 \mathrm{~s}$ and acquired momentum in the last two decades of the $20^{\text {th }}$ century, has been gaining prominence vis-à-vis combating this problem ${ }^{7}$. In Brazil, the Child and Adolescent Statute ${ }^{8}$ made a significant step forward by establishing children and adolescents as individuals entitled to rights and ensuring they are a top priority 9 .

Nevertheless, its actual magnitude still poses a challenge because of the difficulty involved in determining the circumstances under which violence occurs due to a lack of uniformity and integration of records and conceptual differences in typologies ${ }^{10,11}$. Scherer and Scherer ${ }^{11}$ refer to the insufficient training of professionals and to the need to integrate the various victim protection and assistance services.

Violence is a complex phenomenon; it cannot be explained based on a unilinear view of causality but as the result of a particular sociocultural and political context and dynamics signaled by established power relationships that deeply root and frame the social fabric to make the domination of the weaker by the stronger seem natural. The naturalization of violence and domination in relationships must be confronted and overcome $^{12}$.

The WHO defines violence as "the intentional use of physical force or power, threatened or actual, against oneself, another person, or against a group or community, which either results in or has a high likelihood of resulting in injury, death, psychological harm, maldevelopment, or deprivation"1. The Brazilian Ministry of Health considers violence to be events caused by actions imposed on individuals, groups, social classes or countries that result in physical, emotional, moral and/or spiritual damage of oneself or others and differ from accidents, which are unintentional and avoidable ${ }^{13}$. Based on its nature, the WHO classifies violence as physical, psychological, sexual, neglect or abandonment ${ }^{1}$.

Data from the Mortality Information System (Sistema de Informação sobre Mortalidade - SIM) from the Public Health System show that external factors were the main causes of death among children aged one to 10 years old in 2012, with large variations depending on ethnicity/skin color ${ }^{14}$.
Some studies found a larger number of reported violence incidents involving girls ${ }^{15-17}$, while others indicate a predominance of boys among victims $\mathrm{s}^{18,19}$. According to Martins ${ }^{17}$, the estimated global mortality rates by maltreatment are 2.2 cases per 100,000 girls and 1.8 cases per 100,000 boys. According to SIM data, the ratio of deaths by maltreatment among children zero to nine years old in $2012^{14}$ was 1.41 times higher among boys compared to girls.

Even when violence does not leave physical scars, it causes mental and emotional suffering that results in deep traumas for life ${ }^{1,20}$. Several studies have indicated the use of physical violence as a method of child discipline as one of the reasons accounting for such violations of children's rights ${ }^{6,17,19,21-23}$. Violence against children is associated with the violence experienced by their parents in childhood ${ }^{6}$, and domestic violence increases the odds of the affected children becoming homicide victims ${ }^{24}$.

The Brazilian legislation is making steady progress to combat any form of abuse and to protect the rights of children. Article no. 227 of the 1988 Constitution $^{25}$ establishes the right to physical, mental and moral integrity, including the identity, autonomy, values, ideas and right to opine of children and adolescents. The Child Statute provides a significant framework for rights to be maintained. The recently approved Menino Bernardo $\mathrm{Law}^{26}$ aims at changing the ethos of educational practices that transgress children's rights as citizens.

In 2006, the Ministry of Health established the Violence and Accidents Surveillance (Vigilância de Violências e Acidentes - Viva) system, which has two components: a) Survey-based surveillance, conducted at the entrance to emergency departments in selected counties, and b) Continuous surveillance, based on mandatory notification of domestic, sexual and other forms of interpersonal or self-inflicted violence ${ }^{15}$. Viva was initially implemented at maternity hospitals, services for sexually transmitted diseases and services for victims of violence and was then extended in 2009 to all healthcare facilities as part of the Notifiable Diseases Information System (Sistema de Informação de Agravos de Notificação - SINAN $)^{15}$. Enactment of Rule no. $104^{27}$, which makes the notification of all incidents involving interpersonal or self-provoked violence mandatory, strengthened the trend to broaden the scope of violence reporting. Accurate knowledge of violent events and their distribution across Brazil is relevant for the identification of the areas with 
the greatest social vulnerabilities to guide the implementation of health actions able to improve the quality of life.

The aim of the present study was to analyze reported cases of violence against children aged up to nine years, 11 months and 29 days old at Brazilian public healthcare facilities.

\section{Methods}

The descriptive-analytical study was based on notified cases of violence against children aged zero to nine years old in Brazil from January 1 to December 31 2011. The database was created with data collected in the "Domestic, sexual and/ or other forms of violence" notification form available at SINAN NET. All healthcare facilities, including reference centers for and outpatient clinics specialized in violence victims, among others, must notify all instances of violence. The corresponding data are processed in the information system by the municipal health secretaries of the corresponding counties and are then sent to state and federal agencies for entry into nationwide database.

The following variables were selected for assessment: (1) demographic characteristics of victims/assisted individuals (gender, age, ethnicity/skin color, presence of disabilities or disorders, area of residence); (2) event characteristics (whether it occurred at home, repeat violence, nature of the injury, affected body part); (3) type of violence; (4) perpetrator's characteristics (relationship to victim, suspected alcohol intake); and (5) progression and follow-up.

The association between the selected variables and the victims clustered by age range (zero to one, two to five, and six to nine years old) was investigated by means of the chi-square test (2). Poisson regression was performed to calculate prevalence ratios (PRs) with 95\% confidence intervals (CIs). The data were processed using Stata version 11 (StataCorp, College Station, TX, United States).

As the investigated intervention represents a continuous action of epidemiological surveillance instituted by the Ministry of Health across the country, informed consent was waived. Nevertheless, the anonymity and confidentiality of the information contained in the records was ensured to protect the identity of the individuals included in the analyzed database. The data were obtained from the Ministry of Health as anonymous, non-identifiable data .

\section{Results}

In 2011, VIVA/SINAN recorded 17,900 incidents of violence against children aged $\leq$ nine years old; $33 \%$ involved children aged zero to one year old; $35.8 \%$ children aged two to five years old; and $31.2 \%$ children aged six to nine years old. Cases involving girls were more frequently reported compared to boys both overall (54.3\%) and per age range $(\mathrm{p}<0.001)$. The percentages of cases involving white- or black/brown-skinned children were similar, while the percentage of cases involving Asian/indigenous children was 1.6\%. The largest proportions of cases corresponded to age range zero to one year old among white children $(51.8 \%)$ and to age range six to nine years old among black/brown children (52.6\%; p < 0.001 ). Disabled children were involved in 5.1\% of the incidents. Most cases occurred in Southeastern Brazil (42.9\%), and the fewest cases occurred in Northern Brazil (8.2\%) (Table 1).

Relative to their characteristics, $73.6 \%$ of the events had occurred at the victim's home; $43.6 \%$ were instances of repeat violence, and that proportion was higher among the children aged six to nine years old $(53.8 \%$; $<<0.001)$. No injury occurred in $39.6 \%$ of the cases, and in the cases with injuries, the head/neck was the most affected body part (35.4\%), followed by the chest/ abdomen/pelvis (33\%). As to their progression, $89.6 \%$ of the children were discharged, while 198 (1.5\%) died; 129 deaths were a direct consequence of violence, and 69 were due to other causes. In total, $61.6 \%$ of the children were referred to outpatient follow-up, and this proportion was higher among the older children, i.e., those aged six to nine years old $(70.7 \%)$. A total of $22.2 \%$ of the cases were admitted to hospitals, and this proportion was higher among the children aged zero to one year old $(32.5 \%$; $\mathrm{p}<0.001)$ (Table 2).

The predominant type of violence was neglect $(\mathrm{n}=7,716 ; 47.5 \%)$, followed by physical $(\mathrm{n}=5,969 ; 38.5 \%)$, sexual $(\mathrm{n}=5,675 ; 37 \%)$ and psychological/moral $(\mathrm{n}=3,772 ; 25.2 \%)$ violence. Physical violence predominated in age range six to nine years old $(44.9 \%)$, followed by age range zero to one year old $(37.6 \%$; $p<0.001)$. Sexual violence was most frequent among the children aged six to nine years old (52.3\%) and least frequent among the ones aged zero to one year old (11.3\%; p < 0.001). Neglect was most frequent among children aged zero to one year old (67.8\%; $\mathrm{p}<0.001$ ), and psychological violence was predominant in the group of children aged six to 


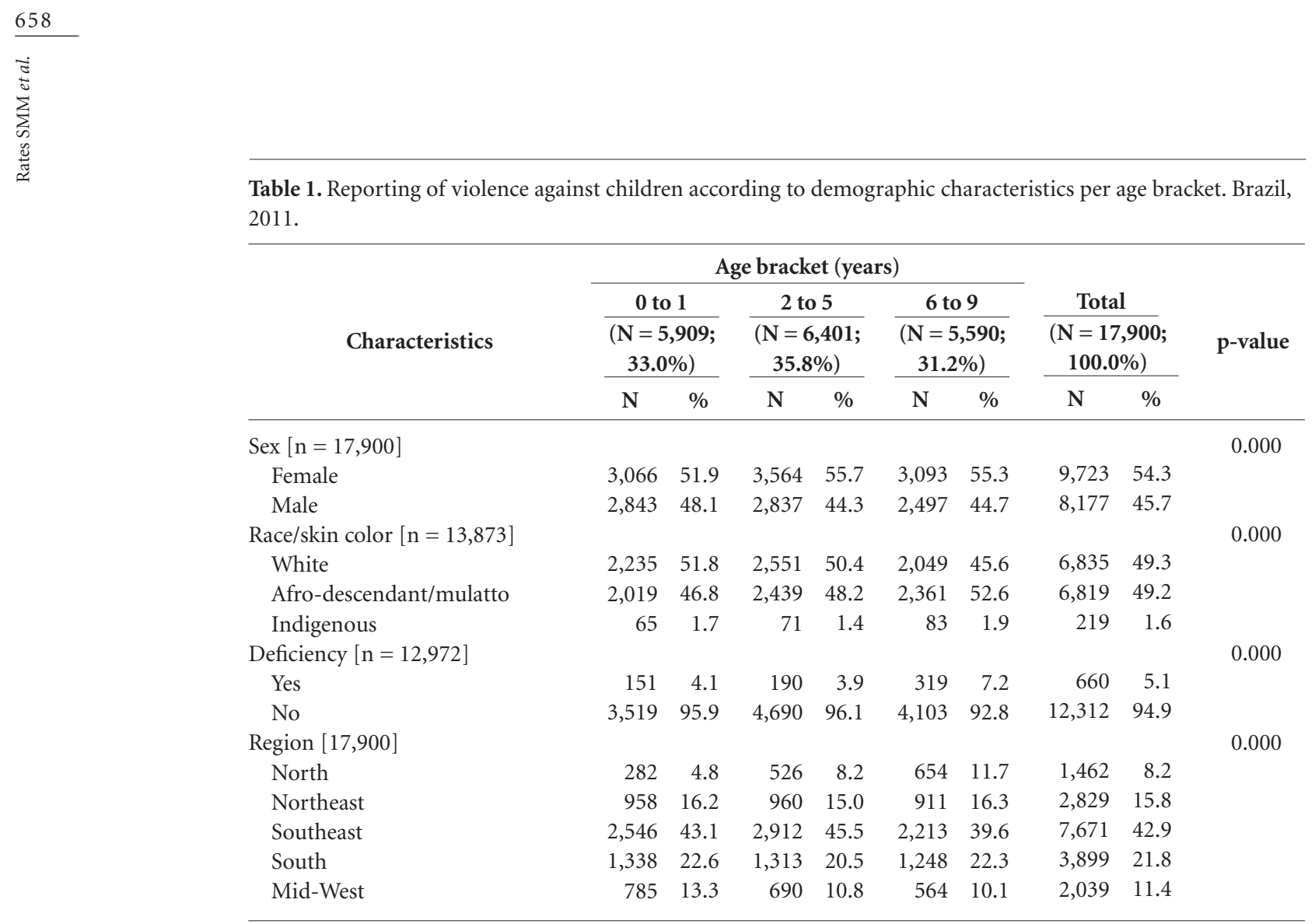

Source: Ministry of Health, Health Surveillance Department, Violence and Accident Surveillance System (SINAN).

nine years old $(38.2 \% ; \mathrm{p}<0.001)$. The children's parents were the most common perpetrators (51.5\%); this proportion was higher among the children aged zero to one year old $(62.4 \%)$, followed by those aged two to five (49\%) and those aged six to nine $(43 \%)$ years old. In $23.8 \%$ of the cases, the perpetrator was suspected of having used alcohol; this proportion was higher among the children aged six to nine years old $(26.3 \%$; $p$ $<0.001)$. A total of 337 cases of torture were reported $(2.3 \%)$, and there were legal interventions in 62 cases $(0.4 \%)$ (Table 3$)$.

Table 4 describes the PRs of the main types of violence against children according to selected characteristics. Physical violence was predominant among boys (PR: 1.22; 95\% CI: 1.16-1.28), especially among those aged six to nine years old (PR: 1.19; 95\% CI: 1.12-1.27), and was least frequent among those aged two to five years old (PR: 0.89; 95\% CI: 0.83-0.95). Offenders other than the children's parents were the most prevalent perpetrators of the violence, and most had used alcohol (PR: 1.36; 95\% CI: 1.27-1.47).

Sexual violence was prevalent among girls, especially among black/brown girls (PR: 1.12; 95\% CI: 1.06-1.19), and the odds were greater among those aged six to nine years old (PR: 4.63; 95\% CI: 4.22-5.08), followed by those aged two to five years old (PR: 1.44; 95\% CI: 1.35-1.54).

Psychological violence was prevalent among girls, especially among black/brown children (PR: 1.10; 95\% CI: 1.03-1.18), and the odds were greater among those aged six to nine years old (PR: 2.95; 95\% CI: 2.69-3.23), followed by those aged two to five years old (PR: 1.88 ; 95\% CI: 1.71-2.07). The odds of violent incidents at home were highest (PR: 1.40; 95\% CI: 1.29-1.53), and offenders other than the children's parents were the most prevalent perpetrators. Most perpetrators were reported as having consumed alcohol (PR: 1.92; 95\% CI: 1.77-2.10), and the odds were higher for repeat violence (PR: 2.62; 95\% CI: 2.42-2.84).

Neglect was prevalent among boys (PR: 1.33; 955 CI: 1.27-1.39), without any difference based on ethnicity/skin color; the odds of occurrence were highest among the children aged zero to one year old. This type of violence was most frequent outside the children's homes, the most prevalent perpetrators were the children's parents (PR: 2.60; 95\% CI: 2.47-2.74), the event was most often not a repeat incident (PR: 0.79; 95\% CI: $0.74-$ 
Table 2. Reporting of violence against children according to occurrence and region characteristics per age bracket. Brazil, 2011.

\begin{tabular}{|c|c|c|c|c|c|c|c|c|c|}
\hline \multirow{3}{*}{ Characteristics } & \multicolumn{6}{|c|}{ Age bracket (years) } & & & \multirow{3}{*}{$\begin{array}{c}\text { p- } \\
\text { value }\end{array}$} \\
\hline & \multicolumn{2}{|c|}{$\begin{array}{c}0 \text { to } 1 \\
(\mathrm{~N}=5,909 ; \\
33.0 \%) \\
\end{array}$} & \multicolumn{2}{|c|}{$\begin{array}{c}2 \text { to } 5 \\
(\mathrm{~N}=6,401 ; \\
35.8 \%)\end{array}$} & \multicolumn{2}{|c|}{$\begin{array}{c}6 \text { to } 9 \\
(\mathrm{~N}=5,590 ; \\
31.2 \%)\end{array}$} & \multicolumn{2}{|c|}{$\begin{array}{c}\text { Total } \\
(\mathrm{N}=17,900 ; \\
100.0 \%)\end{array}$} & \\
\hline & $\mathrm{N}$ & $\%$ & $\mathbf{N}$ & $\%$ & $\mathbf{N}$ & $\%$ & $\mathbf{N}$ & $\%$ & \\
\hline Occurrence in the home $[n=15,655]$ & & & & & & & & & 0.000 \\
\hline Yes & 3,536 & 69.8 & 4,322 & 77.5 & 3,661 & 73.0 & 11,519 & 73.6 & \\
\hline No & 1,527 & 30.2 & 1,252 & 22.5 & 1,357 & 27.0 & 4,136 & 26.4 & \\
\hline Repeated violence $[n=10,568]$ & & & & & & & & & 0.000 \\
\hline Yes & 1,083 & 35.4 & 1,463 & 39.7 & 2,057 & 53.8 & 4,603 & 43.6 & \\
\hline No & 1,980 & 64,6 & 2,219 & 60,3 & 1,766 & 46,2 & 5,965 & 56,4 & \\
\hline Nature of injury $[\mathrm{n}=13,634]$ & & & & & & & & & 0.000 \\
\hline Bruise/sprain/wrench & 570 & 11.9 & 577 & 12.1 & 624 & 15.3 & 1,771 & 13.0 & \\
\hline Cut/amputation & 461 & 9.6 & 542 & 11.4 & 543 & 13.3 & 1,546 & 11.3 & \\
\hline Fracture/traumas & 612 & 12.8 & 401 & 8.4 & 269 & 6.6 & 1,282 & 9.4 & \\
\hline Others & 1,246 & 26.0 & 1,464 & 30.7 & 920 & 22.6 & 3,630 & 26.6 & \\
\hline No injury & 1,906 & 39.8 & 1,781 & 37.4 & 1,718 & 42.2 & 5,405 & 39.6 & \\
\hline Body segment affected $[\mathrm{n}=8,362]$ & & & & & & & & & 0.000 \\
\hline Head/neck & 1,278 & 48.2 & 919 & 29.9 & 760 & 28.8 & 2,957 & 35.4 & \\
\hline Thorax/abdomen/pelvis & 465 & 17.5 & 1,208 & 39.3 & 1,086 & 41.2 & 2,759 & 33.0 & \\
\hline Upper members & 320 & 12.1 & 296 & 9.6 & 279 & 10.6 & 895 & 10.7 & \\
\hline Lower members & 185 & 7.0 & 236 & 7.7 & 233 & 8.8 & 654 & 7.8 & \\
\hline Multiple organs/regions & 404 & 15.2 & 412 & 13.4 & 281 & 10.7 & 1,097 & 13.1 & \\
\hline Evolution $[\mathrm{n}=13,191]$ & & & & & & & & & 0.000 \\
\hline High & 3,675 & 83.7 & 4,322 & 91.5 & 3,827 & 93.9 & 11,824 & 89.6 & \\
\hline Evasion/flight & 593 & 13.5 & 359 & 7.6 & 217 & 5.3 & 1,169 & 8.9 & \\
\hline Death by violence & 75 & 1.7 & 29 & 0.6 & 25 & 0.6 & 129 & 1.0 & \\
\hline Death from other causes & 48 & 1.1 & 12 & 0.3 & 9 & 0.2 & 69 & 0.5 & \\
\hline Place sent in health sector $[\mathrm{n}=13,763]$ & & & & & & & & & 0.000 \\
\hline Outpatient & 2,163 & 49.2 & 3,222 & 64.7 & 3,098 & 70.7 & 8,483 & 61.6 & \\
\hline Inpatient & 1,430 & 32.5 & 1,034 & 20.8 & 593 & 13.5 & 3,057 & 22.2 & \\
\hline No & 808 & 18.4 & 722 & 14.5 & 693 & 15.8 & 2,223 & 16.2 & \\
\hline
\end{tabular}

Source: Ministry of Health, Health Surveillance Department, Violence and Accident Surveillance System (SINAN).

$0.84)$, and most perpetrators were not reported as having consumed alcohol (PR: 0.82; 95\% CI: 0.76-0.89).

Table 5 describes the distribution of the types of violence and corresponding odds of occurrence per geographical area; the results show that violence was prevalent in Southeastern Brazil.

\section{Discussion}

The aim of the present study was to understand the occurrence of violence against children according to its types and determinants to suggest protective actions for victims. Most incidents were cases of domestic violence, affected girls and were perpetrated by the children's parents. Violence was characterized by repeat occurrences, and one-fourth of the perpetrators were reported as having used alcohol. Neglect was the type of violence most often reported, followed by physical, sexual and psychological violence. The odds of physical violence and neglect were higher among boys, and the odds of sexual and psychological violence were higher among girls.

Underreporting and discrepancies among the data on violence against children pose a problem in several parts of the world ${ }^{28-31}$.

In 2006, when VIVA was launched, only 26 counties notified cases. That number increased to $1,496^{15}$ in 2010 and to 3,000 in 2014, which allows for a more thorough understanding of the 
Table 3. Reporting of violence against children according to type of violence and characteristics of the perpetrator by age bracket. Brazil, 2011.

\begin{tabular}{|c|c|c|c|c|c|c|c|c|c|}
\hline \multirow{3}{*}{ Characteristics } & \multicolumn{6}{|c|}{ Age bracket (years) } & & & \multirow{3}{*}{ p-value } \\
\hline & \multicolumn{2}{|c|}{$\begin{array}{c}0 \text { to } 1 \\
(\mathrm{~N}=5,909 ; \\
33.0 \%) \\
\end{array}$} & \multicolumn{2}{|c|}{$\begin{array}{c}2 \text { to } 5 \\
(\mathrm{~N}=6,401 ; \\
35.8 \%) \\
\end{array}$} & \multicolumn{2}{|c|}{$\begin{array}{c}6 \text { to } 9 \\
(\mathrm{~N}=5,590 ; \\
31.2 \%)\end{array}$} & \multicolumn{2}{|c|}{$\begin{array}{c}\text { Total } \\
\mathrm{N}=17,900 \\
100.0 \%)\end{array}$} & \\
\hline & $\mathbf{N}$ & $\%$ & $\mathbf{N}$ & $\%$ & $\mathbf{N}$ & $\%$ & $\mathbf{N}$ & $\%$ & \\
\hline Type of violence & & & & & & & & & 0.000 \\
\hline Physical & 1,863 & 37.6 & 1,863 & 33.5 & 2,243 & 44.9 & 5,969 & 38.5 & 0.000 \\
\hline Psychological/moral & 608 & 12.9 & 1,311 & 24.3 & 1,853 & 38.2 & 3,772 & 25.2 & 0.000 \\
\hline Torture & 90 & 2.0 & 79 & 1.5 & 168 & 3.6 & 337 & 2.3 & 0.000 \\
\hline Sexual & 534 & 11.3 & 2,521 & 44.9 & 2,620 & 52.3 & 5,675 & 37.0 & 0.206 \\
\hline Financial/economic & 44 & 0.9 & 34 & 0.6 & 41 & 0.9 & 119 & 0.8 & 0.000 \\
\hline Negligence & 3,729 & 67.8 & 2,575 & 44.6 & 1,412 & 28.4 & 7,716 & 47.5 & 0.000 \\
\hline Clild labor & 6 & 0.1 & 17 & 0.3 & 38 & 0.8 & 61 & 0.4 & 0.504 \\
\hline Legal Intervention & 22 & 0.5 & 18 & 0.3 & 22 & 0.5 & 62 & 0.4 & 0.000 \\
\hline Others & 285 & 6.2 & 179 & 3.5 & 112 & 2.5 & 576 & 4.0 & 0.000 \\
\hline \multicolumn{10}{|c|}{ Parents $^{\mathrm{a}}$ as perpetrators $[17,900]$} \\
\hline Yes & 3,686 & 62.4 & 3,138 & 49.0 & 2,402 & 43.0 & 9,226 & 51.5 & \\
\hline No & 2,223 & 37.6 & 3,263 & 51.0 & 3,188 & 57.0 & 8,674 & 48.5 & \\
\hline $\begin{array}{l}\text { Ingestion of alcoholic drink } \\
\text { by the perpetrator }[9,280]\end{array}$ & & & & & & & & & 0.000 \\
\hline Yes & 749 & 26.1 & 652 & 19.7 & 811 & 26.3 & 2,212 & 23.8 & \\
\hline No & 2,126 & 74,0 & 2,665 & 80,3 & 2,277 & 73,7 & 7,068 & 76,2 & \\
\hline
\end{tabular}

Source: Ministry of Health, Health Surveillance Department, Violence and Accident Surveillance System (SINAN).

${ }^{a}$ Includes father, mother, stepfather, stepmother.

occurrence of violence in Brazil. This improvement in the surveillance of violence was due to the success of the initial strategy implemented in sentinel services, to a 2011 ministerial order that made notification of victims mandatory, and to the inclusion of this topic in the Public Health Action Organizational Contract ${ }^{32}$. That expansion has contributed to increasing the surveillance actions and the development of networks of delivery of care to victims of violence ${ }^{18,19}$.

The considerable development of an information and handling system notwithstanding, comparisons among regions, states or counties are not yet possible, as Violence Surveillance is at different levels of implementation across the country. A high frequency of notified cases possibly reflects improvements in surveillance, greater commitment of managers and higher sensitization of technical staffs. For that reason, one should not infer that the Southeast is the most violent region in Brazil but rather that more cases are notified due to more advanced establishment of injury surveillance in this area. Significant underreporting ${ }^{19}$ represents one of the main limitations of the present study, as it does not allow considering the notified incidents as representing the full picture of violence against children but as just a fraction or a proxy for the problem. Parallel to improvements in surveillance, the data will increasingly represent the actual violence that is perpetrated in different regions and within domestic settings.

The delicate nature of the problem posed by violence against children is one further factor that points to the need for advances in reporting by training professionals aiming at the care and identification of hidden cases. Some professionals feel uncomfortable when dealing with some cases of abuse $\mathrm{e}^{21,33}$, while others do not perceive signs of violence because the alleged reasons to procure care are masked, and there are some who feel threatened and thus choose not to expose themselves ${ }^{21}$. The distinction between notification and actual occurrence of cases is crucial to recognize the efforts made by the services with the best notification records ${ }^{20}$. However, despite the active participation of professionals in the identification and detection of violent incidents, the data required by the notification forms are self-reported, i.e., provided by the children's par- 
Table 4. Prevalence (\%) and prevalence ratio (PR) of the main types of violence against children according to characteristics. Brazil, 2011.

\begin{tabular}{|c|c|c|c|c|c|c|c|c|}
\hline \multirow{3}{*}{ Characteristics } & \multicolumn{8}{|c|}{ Type of violence } \\
\hline & \multicolumn{2}{|r|}{ Physical } & \multicolumn{2}{|c|}{ Psychological } & \multicolumn{2}{|r|}{ Sexual } & \multicolumn{2}{|r|}{ Negligence } \\
\hline & $\%$ & PR (CI 95\%) & $\%$ & PR (CI 95\%) & $\%$ & PR (CI 95\%) & $\%$ & PR (CI 95\%) \\
\hline \multicolumn{9}{|l|}{ Sex } \\
\hline Female & 34.9 & 1.00 & 28.8 & 1.00 & 48.4 & 1.00 & 41.3 & 1.00 \\
\hline Male & 42.7 & $1.22(1.16-1.28)$ & 20.9 & $0.72(0.68-0.77)$ & 22.7 & $0.47(0.44-0.50)$ & 54.8 & $1.33(1.27-1.39)$ \\
\hline \multicolumn{9}{|l|}{ Race/skin color } \\
\hline White & 36.8 & 1.00 & 25.1 & 1.00 & 36.3 & 1.00 & 43.9 & 1.00 \\
\hline $\begin{array}{l}\text { Afro-descendant/ } \\
\text { mulatto }\end{array}$ & 39.2 & $1.06(1.00-1.13)$ & 27.6 & $1.10(1.03-1.18)$ & 40.9 & $1.12(1.06-1.19)$ & 44.2 & $1.01(0.96-1.06)$ \\
\hline Indigenous & 37.0 & $1.00(0.79-1.27)$ & 27.5 & $1.10(0.83-1.45)$ & 44.7 & $1.23(0.99-1.52)$ & 40.3 & $0.92(0.73-1.15)$ \\
\hline \multicolumn{9}{|l|}{ Age bracket (years) } \\
\hline 0 to 1 & 37.6 & 1.00 & 12.9 & 1.00 & 11.3 & 1.00 & 67.8 & 1.00 \\
\hline 2 to 5 & 33.5 & $0.89(0.83-0.95)$ & 24.3 & $1.88(1.71-2.07)$ & 44.9 & $3.97(3.62-4.36)$ & 44.6 & $0.66(0.63-0.69)$ \\
\hline 6 to 9 & 44.9 & $1.19(1.12-1.27)$ & 38.2 & $2.95(2.69-3.23)$ & 52.3 & $4.63(4.22-5.08)$ & 28.4 & $0.42(0.39-0.44)$ \\
\hline \multicolumn{9}{|l|}{$\begin{array}{l}\text { Occurrence in the } \\
\text { home }\end{array}$} \\
\hline No & 37.5 & 1.00 & 20.1 & 1.00 & 28.1 & 1.00 & 53.0 & 1.00 \\
\hline Yes & 38.0 & $1.01(0.95-1.08)$ & 28.2 & $1.40(1.29-1.53)$ & 38.8 & $1.38(1.29-1.48)$ & 44.9 & $0.85(0.80-0.89)$ \\
\hline \multicolumn{9}{|l|}{$\begin{array}{l}\text { Parents }{ }^{\mathrm{a}} \text { as } \\
\text { pepetrators }\end{array}$} \\
\hline No & 43.6 & 1.00 & 26.5 & 1.00 & 53.7 & 1.00 & 25.7 & 1.00 \\
\hline Yes & 33.3 & $0.76(0.73-0.80)$ & 24.0 & $0.90(0.85-0.96)$ & 20.0 & $0.37(0.32-0.40)$ & 66.7 & $2.60(2.47-2.74)$ \\
\hline \multicolumn{9}{|l|}{ Repeated violence } \\
\hline No & 39.5 & 1.00 & 16.8 & 1.00 & 31.2 & 1.00 & 45.5 & 1.00 \\
\hline Yes & 41.9 & $1.06(1.00-1.13)$ & 44.1 & $2.62(2.42-2.84)$ & 45.0 & $1.44(1.35-1.54)$ & 35.8 & $0.79(0.74-0.84)$ \\
\hline \multicolumn{9}{|l|}{$\begin{array}{l}\text { Ingestion of } \\
\text { alcoholic drink by } \\
\text { the perpetrator }\end{array}$} \\
\hline No & 35.9 & 1.00 & 22.1 & 1.00 & 33.8 & 1.00 & 46.2 & 1.00 \\
\hline Yes & 49.0 & $1.36(1.27-1.47)$ & 42.5 & $1.92(1.77-2.10)$ & 35.8 & $1.06(0.97-1.15)$ & 37.8 & $0.82(0.76-0.89)$ \\
\hline
\end{tabular}

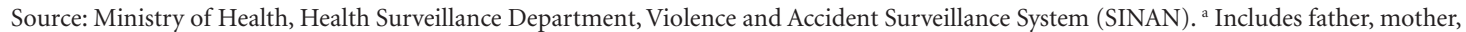
stepfather, stepmother. CI 95\%: confidence interval of 95\%. Statistically significant differences are emphasized in bold print $(\mathrm{p}<0,05)$.

Table 5. Prevalence (\%) and prevalence ratio (PR) of the main types of violence against children according to characteristics. Brazil, 2011.

\begin{tabular}{|c|c|c|c|c|c|c|c|c|}
\hline \multirow{3}{*}{ Characteristics } & \multicolumn{8}{|c|}{ Type of violence } \\
\hline & \multicolumn{2}{|r|}{ Physical } & \multicolumn{2}{|c|}{ Psychological } & \multicolumn{2}{|r|}{ Sexual } & \multicolumn{2}{|r|}{ Negligence } \\
\hline & $\%$ & PR (CI 95\%) & $\%$ & PR (CI 95\%) & $\%$ & PR (CI 95\%) & $\%$ & PR (CI 95\%) \\
\hline \multicolumn{9}{|l|}{ Region } \\
\hline Mid-West & 29.1 & 1.00 & 18.6 & 1.00 & 26.4 & 1.00 & 59.6 & 1.00 \\
\hline North & 39.3 & $1.35(1.20-1.52)$ & 44.1 & $2.37(2.08-2.71)$ & 72.1 & $2.73(2.45-3.04)$ & 20.2 & $0.34(0.30-0.39)$ \\
\hline Northeast & 41.2 & $1.42(1.28-1.57)$ & 24.2 & $1.30(1.14-1.49)$ & 33.1 & $1.25(1.12-1.40)$ & 51.9 & $0.87(0.80-0.94)$ \\
\hline Southeast & 43.2 & $1.49(1.36-1.63)$ & 20.4 & $1.09(0.97-1.23)$ & 37.1 & $1.40(1.28-1.55)$ & 47.4 & $0.80(0.74-0.85)$ \\
\hline South & 33.1 & $1.14(1.03-1.26)$ & 30.0 & $1.61(1.43-1.82)$ & 31.2 & $1.18(1.06-1.31)$ & 48.7 & $0.82(0.76-0.88)$ \\
\hline
\end{tabular}

Source: Ministry of Health, Health Surveillance Department, Violence and Accident Surveillance System (SINAN). CI 95\%: confidence interval of $95 \%$. Statistically significant differences are emphasized in bold print $(\mathrm{p}<0,05)$. 
ents, guardians or chaperons; thus, the possibility of information bias cannot be ruled out. It is worth observing that the present study found that not all the fields in the notification form were filled out; the omissions (i.e., blank, missing and ignored data) resulted in differences in the total numbers of cases among the investigated variables.

The domestic environment was highly significant, and the number of repeat incidents was high, particularly among children aged six to nine years old, which contribute to the perpetuation of the cycle of suffering and deep traumas in the lives of the affected children ${ }^{1,20}$. Physical, sexual and psychological violence predominated among the children aged six to nine years old, and neglect was most common among those under one year old. The children's parents were the main perpetrators of violent incidents, while the number of perpetrators suspected of having used alcohol was significant.

These findings demand some reflections on the dialectics of violence. While transculturally imposed gender relationships cause girls and women to be particularly exposed to some types of violence $e^{1,15,19,34-37}$, the male universe and its power symbols result in men and boys being exposed to other types, such as physical violence, and they tend to be the main victims of aggressions and urban violence ${ }^{1,17,18,38}$. In the present study, we found that boys exhibited the highest PRs of physical violence and neglect, while girls exhibited the highest PRs of psychological and sexual violence.

Deslandes et al. ${ }^{20}$ describe violence as a global problem present in families from any social class and with any religion or beliefs and observe that its effects result from the interaction of the various levels of inclusion in the citizenship of a society. Nevertheless, black citizens are the main victims of social and economic inequities, even though violence affects different social strata and ethnic/skin color groups ${ }^{22,39}$. Those features were detected in the present study, mainly relative to psychological and sexual violence.

The Brazilian and international literature confirms the results of the present study indicating the domestic environment as the preferential locus of interpersonal violence perpetrated by the children's parents or other relatives s,16-20,35,40,41. $^{\text {. }}$ That situation is partially due to the fact that children spend more time at home than anywhere else and to the links between violence and the cultural process of "educating" children by means of punishment and threats ${ }^{18,19}$. As a re- sult, the family home, which should be a place of protection and education, becomes a stage for violence of different types, power/duty transgressions and objectification of childhood ${ }^{20}$. Any form of structural violence affecting the family should also be taken into consideration, as it contributes to the perpetuation of interpersonal violence in the home setting ${ }^{1,20}$.

Alcohol use by perpetrators is a risk factor often described in the literature ${ }^{15,19,33,42}$. It was present in one-fourth of the incidents analyzed in the present study and was most frequently reported for the perpetrators of violence against children aged zero to one year old.

The results of the present study show that the head/neck was the body area most affected, followed by the chest/abdomen/pelvis; these findings agree with reports by Malta et al. ${ }^{19}$ and Martins ${ }^{17}$. The United Nations Children's Fund $(\text { UNICEF) })^{35}$ describes "shaken baby syndrome" as the cause of many head injuries. Assis and Deslandes ${ }^{43}$ observed that trauma is more frequent in the head and abdomen as are burns in the perineum, chest, buttocks and thighs.

In agreement with the literature ${ }^{6,15,17,19}$, according to which mild cases are most prevalent, most cases analyzed in the present study were mild, and the children were discharged; this fact does not make the problem any less serious. Approximately one-fourth of the children required hospital admission, and 198 died, which is indicative of the victims' vulnerability.

Among the violence types, neglect was the most frequent, affecting mainly children aged zero to one year old and boys, a trend that was indicated by VIVA ${ }^{15}$. Different from the present study, a survey conducted by UNICEF $^{35}$ found girls to be more exposed to neglect and violence than boys, especially children with disabilities. One study conducted in the United States found that $45 \%$ of aggressions perpetrated against children were instances of family neglect ${ }^{22}$. Neglect permeates all forms of lack of or insufficient physical, emotional and social care that also affect the family as a whole ${ }^{1,20,35}$ but might also be an expression of intentional negligence ${ }^{1}$. Neglect also occurs when mothers are drug addicts ${ }^{44}$. The children's parents were the main perpetrators of violence, which agrees with reports in the literature indicating that parents are significant perpetrators of neglect ${ }^{1,19,21}$.

Physical violence most frequently affected older boys (six to nine years old), thus agreeing with reports in the literature showing that boys are more exposed to physical violence compared 
to girls and that its prevalence increases with age $^{1,17,35}$. There is a higher chance of alcohol use by perpetrators.

In the present study, the odds of sexual violence were higher among girls aged six to nine years old, followed by those aged two to five years old and among black/brown children; these findings agree with reports in the literature ${ }^{18,22,34,36,45-47}$. UNICEF $^{35}$ states that $20 \%$ of adult women and 5 to $10 \%$ of adult men reported having been victims of sexual violence in childhood. The results further showed that in 2002, approximately 150 million girls and 73 million boys under 18 years old were forced to have sexual intercourse or were subjected to other forms of sexual violence involving physical contact. In addition, that study also pointed to repeat violence and violence at home.

The odds of psychological violence were higher among black/brown girls and increased with age. Incidences of psychological violence were repeat offenses and were most frequent in the home setting, and the use of alcohol by perpetrators was frequent. Assis and Avanci ${ }^{48} \mathrm{ob}-$ served that there is little information and few statistical data on this type of violence, which involves depreciating children through humiliations, threats, prohibitions and mocking that undermine their self-esteem; it frequently coexists with other forms of violence $e^{1,20,35,49}$. According to $\mathrm{WHO}^{36}$ estimates, 25 to $50 \%$ of children are subjected to some variety of psychological abuse. In the study conducted by Moura and Reichenheim $^{49}$, most respondents reported the use of psychological violence against children, and the discrepancy between the "spontaneous" narratives and those located in active searches are deserving of attention as an indicator of underreporting. Another study, performed in Iran, also found that most interviewees (52.09\%) had been subjected to psychological abuse ${ }^{23}$.

\section{Conclusion}

If the origin of the history of violence may be traced back to the pre-civilized period of humankind, its deconstruction demands the awareness and commitment of society at large vis-à-vis the inequities existing in the present time. Although the rights of children and youths are described in constitutions and declarations worldwide, their universal application is the goal of social movements, professionals working in this field and the overall population.

Within that context, health plays an important role in developing intersectoral policies and networks (including judiciary, education, health and social work, among others) to potentiate and increase protective actions and others aiming at promoting quality of life at the individual and collective levels ${ }^{13,50,51}$.

The VIVA notification system is a powerful tool to break the silence on and the invisibility of violence. Mandatory notification ${ }^{27}$ represents a significant step in making the dimension and complexity of violence explicit, especially because it also includes the suspected cases. The Ministry of Health's National Policy of Health Promotion is crucial as a function of its intersectoral scope and the investment made in the prevention of illnesses and risks and the integrated treatment of victims ${ }^{52}$.

A broad-scope debate involving society at large is the best path toward the construction of a fairer society, in which all children are assured their right to life and citizenship.

\section{Collaborators}

DC Malta, SMM Rates and EM Melo participated in the study conception and design, data analysis and interpretation, writing of the first version of the manuscript and critical revision and approved the version to be published. MDM Mascarenhas participated in the study conception and design, data analysis and critical revision and approved the version to be published. 


\section{References}

1. Krug EG, Dahlberg LL, Mercy JA, Zwi AB, Lozano R, editors. World report on violence and health. Geneva: WHO; 2002.

2. Organización Mundial de la Salud (OMS), Sociedad Internacional para la Prevención del Maltrato y el Abandono de los Niños. Prevención del maltrato infantil: qué hacer, y cómo obtener evidencias. Paris: OMS; 2009.

3. Finkelhor D, Ormrod RK, Turner HA. The developmental epidemiology of childhood victimization. J Interpers Violence 2009; 24(5):711-731.

4. Oosterlee A, Vink RM, Smit F. Prevalence of family violence in adults and children: estimates using the capture-recapture method. Eur J Public Health 2009; 19(6):586-591.

5. McGee H, Garavan R, Byrne J, O’Higgins M, Conroy RM. Secular trends in child and adult sexual violence-one decreasing and the other increasing: a population survey in Ireland. Eur J Public Health 2011; 21(1):98103.

6. Emery CR, Nguyen HT, Kim J. Understanding child maltreatment in Hanoi: intimate partner violence, low self-control, and social and child care support. J Interpers Violence 2014; 29(7):1228-1257.

7. Minayo MCS. A inclusão da violência na agenda da saúde: trajetória histórica. Cien Saude Colet 2007; 11(Supl.):1259-1267.

8. Brasil. Presidência da Republica. Lei n ${ }^{\circ} 8.069$, de 13 de julho de 1990. Dispõe sobre o Estatuto da Criança e do Adolescente e dá outras providências. Diário Oficial da União 1990; 16 jul.

9. Digiácomo MJ, Digiácomo IA. Estatuto da criança e do adolescente anotado e interpretado. Curitiba: Ministério Público do Estado do Paraná; 2010.

10. Dahlberg LL, Krug EG. Violência: um problema global de saúde pública. Cien Saude Colet 2006; 11(Supl.):1163-1178.

11. Scherer EA, Scherer ZAP. A criança maltratada: uma revisão da literatura. Rev Latino-am Enfermagem 2000; 8(5):22-29.

12. Ferreira KMM. Violência doméstica/intrafamiliar contra crianças e adolescentes - nossa realidade. In: Silva LMP, organizador. Violência doméstica contra a criança e o adolescente. Recife: EDUPE; 2002. p. 17-43.

13. Brasil. Ministério da Saúde. Portaria GM/MS nº737 de 16 de maio de 2001. Dispõe sobre Política Nacional de Redução da Morbimortalidade por Acidentes e Violências. Diário Oficial da União 2001; 18 maio.

14. Brasil. Ministério da Saúde (MS). Sistema de Informação sobre Mortalidade. 2012. [acessado 2013 mar 25]. Disponível em: http://www2.datasus.gov.br/DATASUS /index.php?area $=040701$

15. Brasil. Ministério da Saúde (MS). Secretaria de Vigilância em Saúde. Departamento de Vigilância de Doenças e Agravos não Transmissíveis e Promoção da Saúde. Sistema de Vigilância de Violências e Acidentes (Viva): 2009, 2010 e 2011. Brasília: MS; 2013.
16. Carvalho ACR, Barros SG, Alves AC, Gurgel CA. Maustratos: estudo através da perspectiva da delegacia de proteção à criança e ao adolescente em Salvador, Bahia. Cien Saude Colet 2009; 14(2):539-546.

17. Martins CBG. Maus tratos contra crianças e adolescentes. Rev Bras Enferm 2010; 63(4):660-665.

18. Mascarenhas MDM, Malta DC, Silva MMA, Lima CM, Carvalho MGO, Oliveira VLA. Violência contra a criança: revelando o perfil dos atendimentos em serviços de emergência, Brasil, 2006 e 2007. Cad Saude Publica 2010; 26(2):347-357.

19. Malta DC, Mascarenhas MDM, Silva MMA, Macario EM. Perfil dos Atendimentos de Emergência por Acidentes envolvendo Crianças Menores de 10 anos Brasil, 2006 a 2007. Cien Saude Colet 2009; 14(5):1669-1679.

20. Deslandes SF, Assis SG, Santos NC. Violência envolvendo crianças no Brasil: um plural estruturado e estruturante. In: Brasil. Ministério da Saúde (MS). Impacto da violência na saúde dos brasileiros. Brasília: MS; 2005. p. 43-77.

21. Deslandes SF. Atenção a crianças e adolescentes vítimas de violência doméstica: análise de um serviço. Cad Saude Publica 1994; 10(Supl. 1):177-187.

22. Costa MC, Carvalho RC, Santa Bárbara JF, Santos CA, de A Gomes W, Lima de Sousa H. The profile of violence against children and adolescents according to Child Protection Council records: victims, aggressors and patterns of violence. Cien Saude Colet 2007; 12(5):1129-1141.

23. Mikaeili N, Barahmand U, Abdi R. The prevalence of different kinds of child abuse and the characteristics that differentiate abused from nonabused male adolescents. J Interpers Violence 2013; 28(5):975-96.

24. Hamilton LHA, Jaffe PG, Campbell M. Assessing children's risk for homicide in the context of domestic violence. J Fam Viol 2013; 28(2):179-189.

25. Brasil. Constituição da República Federativa do Brasil de 1988. Diário Oficial da União 1988; 5 out.

26. Brasil. Lei n. 13.010, de 26 de junho de 2014. Altera a Lei n. 8.069, de 13 de julho de 1990 (Estatuto da Criança e do Adolescente), para estabelecer o direito da criança e do adolescente de serem educados e cuidados sem o uso de castigos físicos ou de tratamento cruel ou degradante, e altera a Lei n. 9.394, de 20 de dezembro de 1996. Diário Oficial da União 2014; 27 jun.

27. Brasil. Ministério da Saúde (MS). Portaria no 104, de 25 de janeiro de 2011. Define as terminologias adotadas em legislação nacional, conforme o disposto no Regulamento Sanitário Internacional 2005 (RSI 2005), a relação de doenças, agravos e eventos em saúde pública de notificação compulsória em todo o território nacional e estabelece fluxo, critérios, responsabilidades e atribuições aos profissionais e serviços de saúde. Diário Oficial da União 2011; 26 jan. 
28. Tursz A, Crost M, Gerbouin-Rérolle P, Cook JM. Underascertainment of child abuse fatalities in France: retrospective analysis of judicial data to assess underreporting of infant homicides in mortality statistics. Child Abuse Negl 2010; 34(7):534-544.

29. Feng JY1, Huang TY, Wang CJ. Kindergarten teachers' experience with reporting child abuse in Taiwan. Child Abuse Negl 2010; 34(2):124-128.

30. Fuhua Zhai, Qin Gao. Child maltreatment among Asian Americans: characteristics and explanatory framework. Child Maltreat 2009; 14(2):207-224.

31. Goodman K. Parent-youth discrepancies in ratings of youth victimization: associations with psychological adjustment. Am J Orthopsychiatry 2013; 83(1):37-46.

32. Brasil. Ministério da Saúde. Resolução no 3, de 30 de janeiro de 2012. Dispõe sobre normas gerais e fluxos do Contrato Organizativo da Ação Pública de Saúde (COAP) no âmbito do Sistema Único de Saúde (SUS). Diário Oficial da União 2012; 31 jan.

33. Souza ER, Jorge MHPM. Impacto da violência na infância e adolescência brasileiras: magnitude da morbimortalidade. In: Lima CA, organizadora. Violência faz mal à saúde. Brasília: Ministério da Saúde; 2006. p. 23-28.

34. Gomes R, Minayo MCS, Souza ER. Violência contra a mulher: uma questão transnacional e transcultural das relações de gênero. In: Brasil. Ministério da Saúde (MS). Impacto da violência na saúde dos brasileiros. Brasília: MS; 2005. p. 117-140.

35. Fundo das Nações Unidas para a Infância (UNICEF). Estudo das Nações Unidas sobre a violência contra as crianças. UNICEF, 2006. [acessado $2013 \mathrm{dez}$ 9]. Disponível em: http://www.unicef.org/brazil/pt/ Estudo_ PSP_Portugues.pdf

36. Organização Mundial da Saúde (OMS). Global Status Report on Violence Prevention. 2008. [acessado 2013 nov 26]. Disponível em: www.who.int/violence_injury_prevention/violence/status_report/ global_status_violence_prevention.pdf?ua $=1$.

37. Guimarães I. Violência de gênero. In: Lima CA, organizadora. Violência faz mal à saúde. Brasília: Ministério da Saúde; 2006. p. 105-109.

38. Reichenheim ME, Souza ER, Moraes CL, Jorge MHPM, Silva CMFP, Minayo MCS. Violência e lesões no Brasil: efeitos, avanços alcançados e desafios futuros. Lancet 2011; 6(Supl. 5):75-89.

39. Oliveira F. Saúde da população negra: Brasil, ano 2001. Brasília: Organização Pan-Americana da Saúde; 2003.

40. Bazon MR. Violências contra crianças e adolescentes: análise de quatro anos de notificações feitas ao Conselho Tutelar na cidade de Ribeirão Preto, São Paulo, Brasil. Cad Saude Publica 2008; 24(2):323-332.

41. Sengoelge M, Hasselberg M, Laflamme L. Child home injury mortality in Europe:a 16-country analysis. Eur J Public Health 2011; 21(2):166-170.
42. Gawryszewski VP, Silva MM, Malta DC, Kegler SR, Mercy JA, Mascarenhas MD, Neto OL. Violence-related injury in emergency departments in Brazil. Rev Panam Salud Publica 2008; 24(6):400-408.

43. Assis SG, Deslandes SF. Abuso físico em diferentes contextos de socialização infanto-juvenil. In: Lima CA, organizadora. Violência faz mal à saúde. Brasília: Ministério da Saúde; 2006. p. 47-58.

44. Manly JT1, Oshri A, Lynch M, Herzog M, Wortel S. Child neglect and the development of externalizing behavior problems: associations with maternal drug dependence and neighborhood crime. Child Maltreat 2013; 18(1):17-29.

45. Souza ER, Lima MLC, Veiga JPC. Violência interpessoal: homicídios e agressões. In: Brasil. Ministério da Saúde. Impacto da violência na saúde dos brasileiros. Brasília: Ministério da Saúde; 2005. p. 171-204.

46. Oliveira AC. Análise do processo de notificação compulsória de maus-tratos/abuso sexual contra crianças e adolescentes no âmbito da SES/RJ - 2000 a 2002. Rio de Janeiro; Secretaria de Estado de Saúde; 2004.

47. Felizardo D, Zürcher E, Melo K. Violência sexual: conceituação e atendimento. In: Lima CA, organizadora. Violência faz mal à saúde. Brasília: Ministério da Saúde; 2006. p. 69-80.

48. Assis SG, Avanci JQ. Abuso psicológico e desenvolvimento infantil. In: Lima CA, organizadora. Violência faz mal à saúde. Brasília: Ministério da Saúde; 2006. p. 59-67.

49. Moura ATMS, Reichenheim ME. Estamos realmente detectando violência familiar contra a criança em serviços de saúde? A experiência de um serviço público do Rio de Janeiro, Brasil. Cad Saude Publica 2005; 21(4):1124-1133.

50. Minayo MCS, Souza ER. É possível prevenir a violência? Reflexões a partir do campo da saúde pública. Cien Saude Colet 1999; 4(1):7-23.

51. Deslandes S. Redes de proteção social e redes sociais: uma práxis integradora. In: Lima CA, organizadora. Violência faz mal à saúde. Brasília: Ministério da Saúde; 2006. p. 135-141.

52. Malta DC, Castro AM. Avanços e resultados na implementação da Política Nacional de Promoção da Saúde. $B$ Téc Senac: a R Educ Prof. 2009; 35(2):62-71.

Article submitted on 30/09/2014

Approved on 27/11/2014

Final version submitted on 29/11/2014 
